\title{
34. PETROGRAPHY AND GEOCHEMISTRY OF BASEMENT ROCKS FROM FIVE LEG 60 SITES 1
}

\author{
Anatoly Ya. Sharaskin, Vernadsky Institute of Geochemistry, USSR Academy of Sciences, 117334, Moscow, USSR
}

\begin{abstract}
- Bülk chemistry and trace elements data were measured in 72 samples, selected from 5 basement sections, which have been recovered by Leg 60 drilling (Sites 453, 454, 456, 458, and 459). According to analytical results a metagabbro-metabasalt breccia, deposited about $5 \mathrm{Ma}$ at the westernmost flank of the Mariana Trough (Site 453), was derived from an island arc source. Basalts from the Mariana Trough (Sites 454 and 456) are similar in many respects to midoceanic ridge basalts (MORB). Yet rocks of unusual geochemistry, reflecting the possible influence of arc volcanism, were found among the pillow lavas at the easterrimost trough (Site 456). The acoustic basement in the Mariana fore-arc region was formed by submarine eruptions of arc tholeiites (Sites 458 and 459 ) and peculiar high-MgO andesites related to the boninite suite.
\end{abstract}

\section{INTRODUCTION}

Leg 60 successfully recovered basement rocks at five sites along the marginal basin-island arc transect. In the Mariana Trough, drilling in two holes at (Sites 454 and 456) penetrated pillow basalts intercalated with Pleistocene sediments as expected; the third hole produced a surprise. We encountered a well-cemented polymict breccia underlying Pliocene deposits at the westernmost site (453), which we had hoped would document the earliest opening and presumed basaltic stage of the Mariana Trough. Two other successful penetrations, at Sites 458 and 459 , revealed a pre-Oligocene volcanic series forming the basement roof of the Mariana forearc region.

The purpose of this chapter is to present petrographic descriptions and geochemical data on 72 samples selected from these sites.

\section{ANALYTICAL METHODS}

Prior to analyses the rock chips were washed in ethyl alcohol and hot distilled water to eliminate drilling lubricant or seawater contamination.

Major element data were measured on glassy discs by X-ray fluorescence using a standard Philips PW-1600 unit. Fifteen samples were further analyzed by wet chemical methods to check the accuracy of the $\mathrm{XRF}$ technique; the results were in perfect agreement. Ignition losses and $\mathrm{Fe}_{2} \mathrm{O}_{3} / \mathrm{FeO}$ ratios are based on separate chemical determinations.

Mineral and glass compositions were analyzed by microprobe techniques using a series of the natural standards. $\mathrm{H}_{2} \mathrm{O}^{+}$content in basaltic glasses was measured in separated $20-\mathrm{mg}$ probes by gas chromatography.

Methods for analysis of trace elements were as follows: $\mathrm{Rb}$ and $\mathrm{Li}$-flame photometry; $\mathrm{Sr}, \mathrm{Ba}, \mathrm{Zr}$, and $\mathrm{Y}$-emission spectroscopy; $\mathrm{Cr}, \mathrm{Ni}, \mathrm{Co}, \mathrm{V}$, and $\mathrm{Cu}-$ atomic absorption. International rock standards CRPG-BR, GSJ-JB-1, and USGS-AGV-1 were used to check accuracy of analysis.

\section{CLASTS OF METAMORPHOSED IGNEOUS ROCKS FROM THE POLYMICT BRECCIA: SITE 453}

The polymict breccia, penetrated in Hole 453 to 150 meters below the contact with overlaying sediments,

\footnotetext{
${ }^{1}$ Initial Reports of the Deep Sea Drilling Project, Volume 60.
}

has a complex lithology (see site chapter) and consists mainly of metamorphosed igneous rock fragments. Angular to subrounded, the fragments range from sandsized detritus to lumps as large as $45 \mathrm{~cm}$. Clasts of gabbros, variable in textures and mineral composition, áré the most abundant rock types. Together with less abundant diabase and basalt fragments, they characterize the mafic composition of the brecciated sequences in general, although several other rock types also occur among the breccia material.

As is evident from petrographic observations, both plutonic and effusive rocks underwent metamorphism before brecciation. Although a detailed consideration of metamorphic events is beyond the scope of this chapter, it is important to point out that the intrusive rocks apparently had a more complex metamorphic history than the volcanics. Many gabbros and a single granite fragment show tectonic fabrics and recrystallization under stress conditions. None of these features werre observed in basalts or diabases, although all the rocks eventually experienced a similar retrograde metamorphism. This diversity indicates that the two rock groups may not be cognate but related instead to different episodes of magmatic activity.

Unfortunately an attempt at age determination for three samples (gabbro, 453-55-4, 111-117; granite, 45353-3, 63-67; and diabase, 453-54-3, 13-17) was unsuccessful. The amount of material was insufficient for the accurate measurement of the radiogenic argon concentrations, which were very low in all cases. This result tentatively indicates that the last episode of metamorphism, which produced argon loss, could not have occurred more than 5 to $7 \mathrm{Ma}$.

\section{Metavolcanic Rocks and Fine-Grained Amphibole Gabbros}

Fourteen samples were selected to cover the full variety of metavolcanic rocks among the breccia fragments. In spite of moderate to heavy alterations, all rocks studied have well-preserved original textures, which are mainly subophitic or doleritic both in aphyric and porphyric varieties. Plagioclase is the dominant 
phenocryst mineral and is occasionally accompanied by minor clinopyroxene and rare olivine. Phenocryst to groundmass proportions range from 1 to $2 \%$ up to $45 \%$ by rock volume. Aphyric rocks and the matrix of porphyritic rocks are similar petrographically, consisting of plagioclase, clinopyroxene, and $\mathrm{Fe}$-Ti-oxides.

Carbonate, chlorite, actinolite, sericite, prehnite, pumpellyite, biotite, clay minerals and minor epidote, clinozoisite, quartz, albite, K-feldspar, sphene, iddingsite, and Fe-hydroxides were observed among the secondary mineral assemblages, which are variable from one rock to another. These mineral relations signify a complicated progressive (to greenshist facies) and retrograde (to prehnite-pumpellyite facies) metamorphism before breccia formation, followed by hydrothermal alteration after it.

Major element data on analyzed samples (Table 1) are illustrated by Harker variation diagram (Fig. 1). In addition to petrography, chemical data also suggest the cognate character of rocks under consideration. The negative correlation of the $\mathrm{FeO}$ (as total $\mathrm{Fe}$ ) and $\mathrm{SiO}_{2}$ contents points to the calc-alkaline affinity of the volcanic series, which is in good agreement with trace element geochemical data (Table 2)-i.e., with constantly low $\mathrm{Cr}$ and $\mathrm{Ni}$ but high $\mathrm{Sr}$ and $\mathrm{Ba}$ concentrations. The wide variation in $\mathrm{Ba}, \mathrm{Rb}, \mathrm{Li}$, and $\mathrm{Cu}$ content is obviously due to secondary alteration such as formation of biotite or carbonate.

From a geochemical point of view, two samples of fine-grained amphibole gabbros (Tables 1 and 2) may belong to the same magmatic series, representing its hypabyssal members. They differ sharply from all other gabbros by their higher $\mathrm{Zr}$ and $\mathrm{Y}$ and lower $\mathrm{Cr}$ and $\mathrm{Ni}$ content and are similar in this respect to metavolcanics. Petrographically these are granular rocks with ophitic to poikilitic textures. Brownish-green hornblende and subordinate chlorite-actinolite aggregates replace the primary clinopyroxene, leaving only relicts of this mineral. Plagioclase is largely replaced by sericite and chlorite; $\mathrm{Fe}$-Ti-oxides remain almost unaltered.

One rock, representing scarce acid metavolcanics in the breccias, is quartz albitophyre. It has euhedral zoned albite phenocrysts set into a quartz-albite-biotite groundmass of trachytoid texture, in which accessory $\mathrm{K}$-feldspar and magnetite are also present. The rock looks remarkably fresh, evidently because of the stability of the original mineral paragenesis despite metamorphosis. Geochemically (Tables 1 and 2) it is a normal member of the calc-alkaline rock family.

\section{Metamorphosed Plutonic Rocks}

Eight samples of metamorphosed coarse-grained gabbros represent only a limited number of examples of the varieties observed in breccia. Seven are very similar mineralogically, although the mineral proportions are variable. Their principal constituents are calcic plagioclase, olivine, and clinopyroxene. The anorthositic variants (Samples 453-55-2, 76-79 and 453-55-4, 111-117) contain only rare interstitial and badly altered olivine and clinopyroxene grains, whereas in the more melanocratic rocks these minerals are more idiomorphic and better preserved. Clinopyroxene often forms reaction rims around olivine grains and sometimes has exolution lamellae of orthopyroxene. The $\mathrm{Fe}-\mathrm{Mg}$ minerals are usually replaced by secondary products stronger than plagioclase, but the latter tends to be recrystallized into granoblastic aggre-

Table 1. Major element analyses of rock clasts from the polymict breccia, Hole 453 .

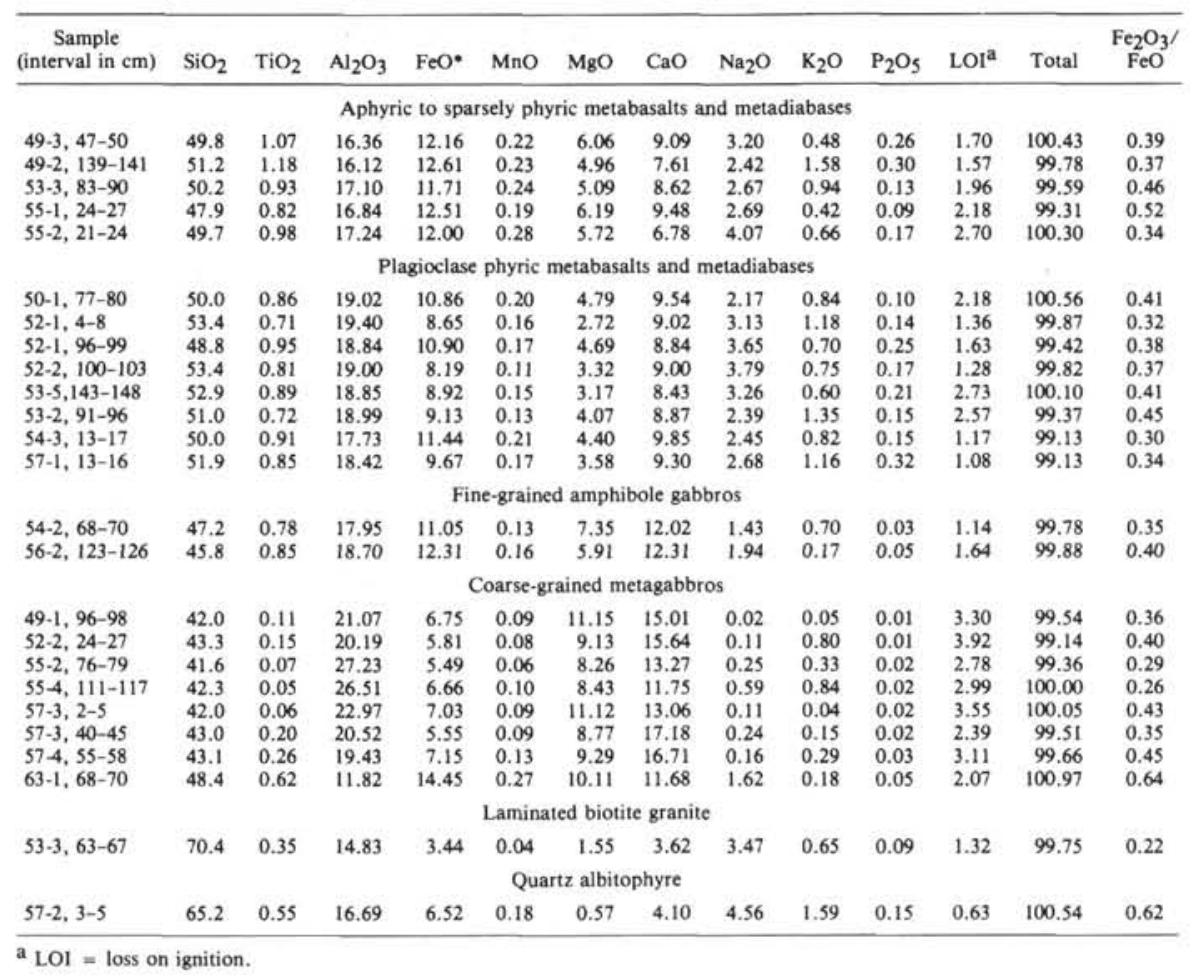




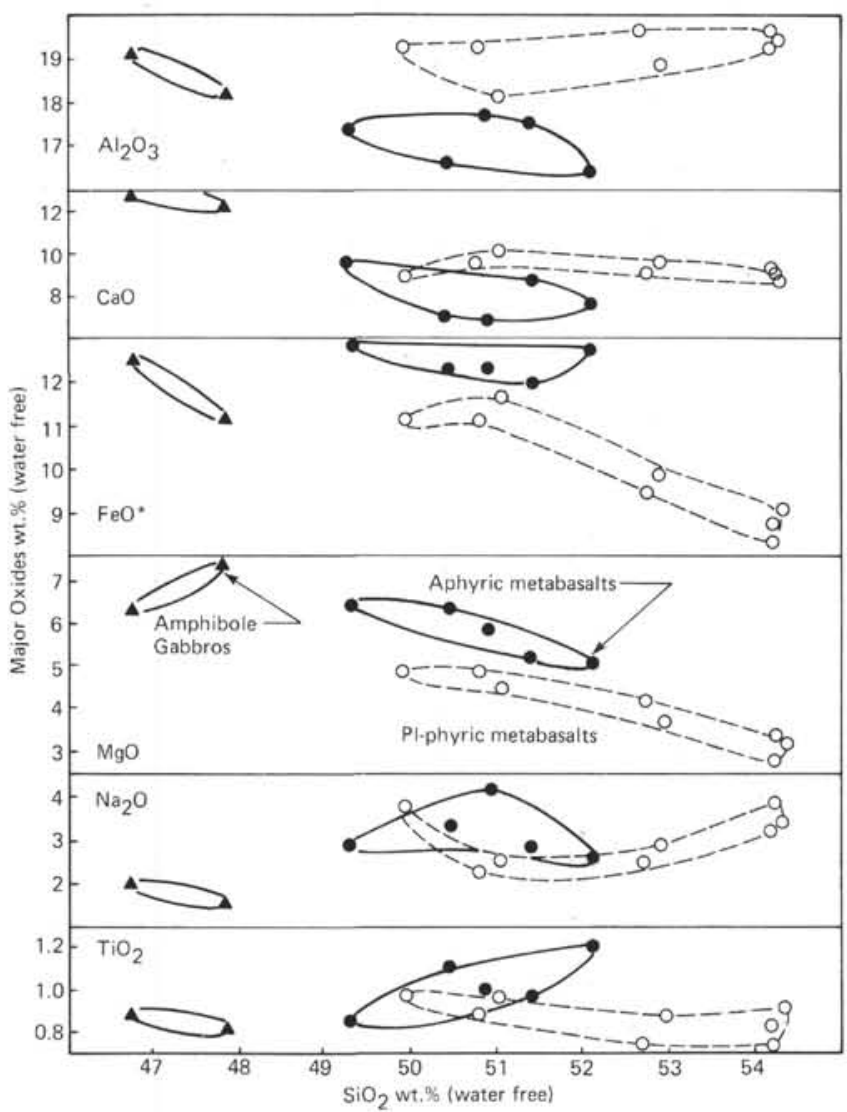

Figure 1. Harker variation diagram for metabasalt and fine-grained amphibole gabbro clasts from Site 453 polymict breccia.

Table 2. Trace element analyses of rock clasts from the polymict breccia, Hole 453.

\begin{tabular}{|c|c|c|c|c|c|c|c|c|c|c|c|}
\hline $\begin{array}{c}\text { Sample } \\
\text { (interval in } \mathrm{cm} \text { ) }\end{array}$ & $\mathrm{Rb}$ & $\mathrm{Li}$ & Sr & $\mathrm{Ba}$ & $\mathrm{Zr}$ & $\mathbf{Y}$ & $\mathrm{Cr}$ & $\mathrm{Ni}$ & $\mathrm{Co}$ & $\mathrm{V}$ & $\mathrm{Cu}$ \\
\hline \multicolumn{12}{|c|}{ Aphyric to sparsely phyric metabasalts and metadiabases } \\
\hline $49-3,47-50$ & 7.2 & 5.1 & 475 & 21 & 60 & 30 & 26 & 11 & 31 & 417 & 326 \\
\hline $49-2,139-141$ & 24.5 & 36.7 & 373 & 266 & 117 & 42 & 11 & 9 & 25 & 370 & 225 \\
\hline $53-3,83-90$ & 14.2 & 8.9 & 578 & 702 & 64 & 39 & 13 & 7 & 22 & 180 & \\
\hline $55-1,24-27$ & 9.5 & 2.4 & $\$ 34$ & 83 & 28 & 17 & 19 & 10 & 22 & 470 & \\
\hline $55-2,21-24$ & 1.9 & 5.6 & 350 & 56 & 88 & 68 & 13 & 9 & 25 & 241 & 156 \\
\hline \multicolumn{12}{|c|}{ Plagioclase phyric metabasalts and metadiabases } \\
\hline $50-1,77-80$ & 11.3 & 22.5 & 567 & 283 & 48 & 21 & 8 & 11 & 28 & 465 & \\
\hline $52-1,4-8$ & 13.3 & & 698 & 384 & 56 & 2 & 5 & 6 & 17 & 156 & 181 \\
\hline $52-1,96-99$ & 4.9 & 6. & 570 & 103 & 56 & 24 & 16 & 8 & 22 & 316 & 236 \\
\hline $52-2,100-103$ & 7 & 3. & 710 & 194 & 99 & 50 & 3 & 6 & 17 & 276 & 59 \\
\hline $53-5,143-148$ & 8.9 & 2 . & 644 & 337 & 125 & 37 & 6 & 9 & 19 & 200 & 150 \\
\hline $53-2,91-96$ & 26.6 & 7.3 & 647 & 593 & 61 & 29 & 12 & 11 & 24 & 472 & \\
\hline $54-3,13-17$ & 6.1 & 2.9 & 485 & 336 & 54 & 21 & 19 & 10 & 22 & 304 & 353 \\
\hline $57-1,13-16$ & 25.1 & 1.3 & 608 & 447 & 99 & 39 & 12 & 12 & 25 & 342 & 155 \\
\hline \multicolumn{12}{|c|}{ Fine-grained amphibole gabbros } \\
\hline $54-2,68-70$ & 20.6 & 3.6 & 359 & 252 & 45 & 44 & 26 & 38 & 44 & 614 & 246 \\
\hline $56-2,123-126$ & 3.6 & 1.7 & 460 & 34 & 31 & 12 & 28 & 13 & 32 & 712 & \\
\hline \multicolumn{12}{|c|}{ Coarse-grained metagabbros } \\
\hline $49-1,96-98$ & 2.3 & 3.6 & 470 & 35 & 6.3 & 3.8 & 117 & 74 & 64 & 94 & 19 \\
\hline $52-2$ & 2.9 & 14.7 & 4 & 229 & 7.0 & 3.0 & 286 & 47 & 45 & 125 & \\
\hline $55-2,76-79$ & 0.9 & 2.2 & 631 & 46 & 6.1 & $<3$ & 20 & 49 & 47 & 16 & \\
\hline $55-4,111-117$ & 5.9 & 2.4 & 424 & 522 & 6.7 & $<3$ & 17 & 37 & 56 & & \\
\hline $57-3,2-5$ & 3.3 & 1.7 & 498 & 11 & 6.5 & $<3$ & 93 & 51 & 58 & 29 & \\
\hline $57-3,40-45$ & 5.4 & 7.9 & 348 & 25 & 7.8 & 4.3 & 362 & 34 & 43 & 103 & \\
\hline & 2.0 & 3.9 & 322 & 150 & 7,4 & 5.0 & 342 & 37 & 39 & 27 & \\
\hline $63-1,68-70$ & 7.3 & 3.2 & 335 & 32 & 20 & 16 & 19 & 21 & 58 & 463 & 38 \\
\hline \multicolumn{12}{|c|}{ Laminated biotite granite } \\
\hline $53-3,63-67$ & 14.3 & 4.8 & 439 & 478 & 39 & 7 & tr & 9 & 15 & 15 & 20 \\
\hline \multicolumn{12}{|c|}{ Quartz albitophyre } \\
\hline $57-2,3-5$ & 15.8 & 1.8 & 429 & 743 & 210 & 100 & 8 & 8 & 11 & 16 & 19 \\
\hline
\end{tabular}

gates. In several samples green spinel grains are associated with altered interstitial pyroxene. Sample 453-63-1, $68-70 \mathrm{~cm}$ is melanocratic, strongly tectonized, and serpentinized gabbro-norite. Lacking olivine and relatively rich in Fe-Ti-oxides, it differs sharply from other gabbros studied.

Except for this last rock, secondary replacements are fairly moderate. After pyroxene, green hornblende, tremolite-actinolite aggregates, chlorite, biotite, and epidote are typical secondary products. Serpentine, magnetite, hematite, and brucite replace olivines, very often as pseudomorphs. Sericite, clinozoisite, prehnite, and pumpellyite develop after plagioclase.

The chemistry of the gabbro samples (Table 1) is consistent with their mineralogy and reflects the variable proportions of plagioclase and $\mathrm{Fe}-\mathrm{Mg}$ minerals. Trace element data (Table 2 ) indicate wide diversity of distribution of certain elements with similar characteristics. In general, this is typical of rocks of cumulate origin but may be caused in part by certain alteration phenomena.

The single granitic fragment in breccia is distinctly foliated biotite-hornblende tonalite of lepidogranoblastic texture. It consists of oligoclase-albite, quartz, amphibole, and magnetite with accessory biotite, $\mathrm{K}$-feldspar, apatite, and zircon. Geochemically (Tables 1 and 2 ) it is depleted in incompatible trace elements as compared with normal continental granites.

\section{BASALTS FROM THE CENTRAL PART OF THE MARIANA TROUGH: SITES 454 AND 456}

Although Sites 454 and 456 are nearly symmetrical relative to the assumed spreading axes of the Mariana Trough, drilling revealed a substantial difference in basement geology. Within the comparable depth intervals, the western (Site 454) and eastern (Site 456) sections are different in lithology, igneous rock types, and degree of alteration. Available data (see site chapters for details) suggest intermittent eruptions of poorly differentiated lavas to the west and steadier magmatic activity with more complex magma composition to the east. The discrepancy grew because of intensive secondary alterations of rocks at Site 456 . Two holes only 200 meters apart exhibit a diversity in the extent and type of rock alteration that suggests a local hydrothermal flux as the main metamorphosing factor. In contrast, Site 454 basalts underwent only halmyrolysis and were in most cases almost fresh.

The shipboard party recognized 5 lithologic units within the 112-meter-thick basement section recovered from Hole 454A. Ten samples were studied to determine the variations in basalt composition along the section. Petrographically they can be divided into three groups.

The first includes glassy to spherulitic sparsely phyric basalts representing the outer pillow rinds. The rocks contain up to $5 \%$ of euhedral, sometimes skeletal olivine microphenocrysts in a fresh, partly devitrified glass with rare microlites of olivine and plagioclase. Samples 454A-6-2, 99-101 cm, 454A-8-1, 17-21 cm, 454A-10-1, $15-18 \mathrm{~cm}$, and $454 \mathrm{~A}-16-1,52-55 \mathrm{~cm}$ belong to this group. 
The rocks of the second group are microphyric basalts with subophitic to intersertal textures, selected from flow or pillow interiors. Both olivine and plagioclase are present in these rocks as microphenocrysts. They are set in the groundmass, which consists of plagioclase laths with plumose augite aggregates between them and some interstitial devitrified glass. Three samples, 454A-5-1, 13-15 cm, 454A-5-4, 12-14 cm, 454A$11-4,72-74 \mathrm{~cm}$, are of this type.

Aphyric basalts with subophitic textures constitute the third group. These rocks characterize the most crystalline parts of the massive flows and are in part the more coarse-grained equivalents of the groundmass from the previous rock group. Three samples 454A-5-2, $43-45 \mathrm{~cm}, 454 \mathrm{~A}-5-3,105-107 \mathrm{~cm}$, and $454 \mathrm{~A}-6, \mathrm{CC}$, $34-36 \mathrm{~cm}$, belong to this group.

The last type is considerably less vesicular than the previous two, in which the vesicularity is $15 \%$ to $20 \%$ by volume. Secondary alteration is negligible in all samples. Olivine and plagioclase crystals commonly contain tiny euhedral inclusions of brown spinel, which are occasionally present as microphenocrysts. The mineral suite indicates spinel and olivine as the first crystalline phases, followed by nearly joint crystallisation of plagioclase clinopyroxene and titanomagnetite.

At Site 456, although penetration of basement was only about 40 meters, several petrographically distinct types of basalts were recovered. They were classified into five units (see site chapter).

Three samples from Hole 456 characterize Unit 1. They are almost entirely altered aphyric to sparsely phyric pillow basalts, which contain only plagioclase relicts in the highly vesicular groundmass, replaced by clay minerals, carbonate, quartz, minor chlorite, and pyrite. Rare pseudomorphs of chlorite, presumably after occasional clinopyroxene microphenocrysts, were observed in Sample 456-16-2, 106-109 cm.

Highly Pl-phyric basalts of Unit 2 occur only in Hole 456A. In Sample 456A-12-1, 6-9 cm, euhedral phenocrysts and glomerocrysts of zoned labradorite occupy about $30 \%$ of the rock volume, accompanied by scarce talc-serpentite-Fe-oxide pseudomorphs after olivine. The altered groundmass was primarily glassy to spherulitic in texture.

Rocks from Units 3 to 5 are badly altered (Sample 456A-13-1, 17-19 cm) or reasonably fresh (Samples 456A-14-1, 18-20 cm and 465A-15-1, 12-14 cm) aphyric to sparsely phyric pillow basalts with small and scarce plagioclase microphenocrysts set into a vesicular intersertal groundmass. The latter consist of olivine, plagioclase, and clinopyroxene microlites, cemented by altered devitrified glass. In Sample 456A-14-1, 5-8 cm olivine is absent; only plagioclase, pyroxene, and altered glass, enriched in opaque dendrites, remain as constituents of this rock.

The chemistry of samples from both sites (Table 3 ) is compared by means of $\mathrm{MgO}$ variation diagrams (Fig. 2 ). These demonstrate a single differentiation trend for all the Site 454 rocks except one. The glassy olivinephyric pillow rinds from this site have a primitive glass composition (Table 4) compared to the aphyric basalts from the massive flow interiors (petrographic group 3 ). Thus the latter may have been produced by within-flow olivine fractionation, which is consistent with the more complex olivine composition in massive flows relative to that in pillow rinds (Table 4).

The low $\mathrm{K}_{2} \mathrm{O}$ and $\mathrm{TiO}_{2}$ contents in the basalts from Site 454 suggest their similarity to mid-ocean ridge basalts (MORB). According to the rather high concentrations of certain trace elements at a given $\mathrm{MgO}$ contents (e.g., $\mathrm{Sr}$ and $\mathrm{Ba}$, Table 5), they are closer to transitional than to normal MORB (Sun et al., 1979). One of the Site 454 samples is distinct from the general trend of compositions from that site, and belongs to a separate chemical unit, recovered in the lowermost part of the penetrated section. Resembling the other pillow rinds in texture and mineralogy, it has a similar level of $\mathrm{MgO}$, $\mathrm{Cr}$, and $\mathrm{Ni}$ content but is definitely enriched in $\mathrm{Ti}, \mathrm{Zr}$, $\mathrm{Y}$, and $\mathrm{Ba}$ (Table 5). Such divergent characteristics were also observed in some Mid-Atlantic Ridge basalts pro-

Table 3. Major element analyses of Mariana Trough basalts, Sites 454 and 456.

\begin{tabular}{|c|c|c|c|c|c|c|c|c|c|c|c|c|c|}
\hline $\begin{array}{c}\text { Sample } \\
\text { (interval in } \mathrm{cm} \text { ) }\end{array}$ & $\mathrm{SiO}_{2}$ & $\mathrm{TiO}_{2}$ & $\mathrm{Al}_{2} \mathrm{O}_{3}$ & $\mathrm{FeO}^{*}$ & $\mathrm{MnO}$ & $\mathrm{MgO}$ & $\mathrm{CaO}$ & $\mathrm{Na}_{2} \mathrm{O}$ & $\mathrm{K}_{2} \mathrm{O}$ & $\mathrm{P}_{2} \mathrm{O}_{5}$ & $\mathrm{LOI}^{\mathrm{a}}$ & Total & $\begin{array}{c}\mathrm{Fe}_{2} \mathrm{O}_{3} / \\
\mathrm{FeO}\end{array}$ \\
\hline \multicolumn{14}{|c|}{ Hole 454A } \\
\hline $5-1,13-15$ & 48.9 & 0.93 & 17.21 & 7.62 & 0.11 & 8.21 & 11.90 & 2.18 & 0.23 & 0.10 & 2.96 & 100.35 & 0.49 \\
\hline $5-2,43-45$ & 49.0 & 0.96 & 16.89 & 7.62 & 0.10 & 7.99 & 11.70 & 2.34 & 0.11 & 0.10 & 2.73 & 99.54 & 0.47 \\
\hline $5-3,105-107$ & 49.0 & 0.93 & 17.14 & 7.34 & 0.10 & 7.46 & 12.38 & 2.38 & 0.11 & 0.10 & 2.35 & 99.29 & 0.47 \\
\hline $5-4,12-14$ & 49.0 & 0.84 & 17,18 & 7.50 & 0.11 & 9.82 & 11.80 & 1.89 & 0.13 & 0.09 & 1.39 & 99.75 & 0.27 \\
\hline $6-2,99-101$ & 48.7 & 0.95 & 16.34 & 8.05 & 0.12 & 10.08 & 11.34 & 2.02 & 0.31 & 0.10 & 1.93 & 99.94 & 0.61 \\
\hline $6, \mathrm{CC}, 34-36$ & 49.4 & 0.90 & 16.70 & 7.42 & 0.10 & 8.35 & 11.70 & 2.36 & 0.09 & 0.09 & 2.69 & 99.58 & 0.33 \\
\hline $8-1,17-21$ & 49.1 & 0.88 & 16.33 & 8.17 & 0.13 & 10.63 & 11.38 & 1.84 & 0.33 & 0.10 & 1.69 & 100.58 & 0.22 \\
\hline $10-1,15-18$ & 49.0 & 0.87 & 16.20 & 8.05 & 0.13 & 10.55 & 11.42 & 1.92 & 0.28 & 0.10 & 1.60 & 100.12 & 0.24 \\
\hline $11-4,72-74$ & 49.0 & 0.90 & 17.17 & 7.53 & 0.11 & 8.28 & 11.55 & 2.20 & 0.29 & 0.09 & 2.13 & 99.25 & 0.39 \\
\hline $16-1,52-55$ & 50.2 & 1.11 & 15.55 & 8.58 & 0.14 & 9.46 & 10.37 & 2.37 & 0.50 & 0.13 & 1.43 & 99.84 & 0.50 \\
\hline \multicolumn{14}{|c|}{ Hole 456} \\
\hline $16-1,23-25$ & 47.4 & 1.09 & 15.74 & 7.18 & 0.18 & 5.70 & 12.26 & 2.19 & 0.04 & 0.11 & 8.59 & 100.48 & 0.61 \\
\hline $16-1,76-77$ & 48.4 & 1.12 & 16.25 & 8.19 & 0.15 & 7.78 & 7.66 & 3.69 & 0.21 & 0.13 & 6.39 & 99.97 & 0.66 \\
\hline $16-2,106-109$ & 47.4 & 1.04 & 15.76 & 8.24 & 0.25 & 7.16 & 9.87 & 2.31 & 0.06 & 0.12 & 7.26 & 99.47 & 0.60 \\
\hline \multicolumn{14}{|c|}{ Hole 456A } \\
\hline $12-1,6-9$ & 45.9 & 0.73 & 22.59 & 5.26 & 0.03 & 7.89 & 9.06 & 2.42 & 0.12 & 0.07 & 4.93 & 99.00 & 0.76 \\
\hline $13-1,17-19$ & 49.5 & 1.01 & 18.50 & 7.31 & 0.07 & 7.76 & 6.27 & 3.25 & 0.23 & 0.16 & 6.57 & 99.68 & 1.11 \\
\hline $14-1,5-8$ & 52.2 & 1.26 & 16.35 & 9.39 & 0.17 & 4.52 & 9.92 & 3.85 & 0.83 & 0.18 & 2.24 & 100.50 & 0.79 \\
\hline $14-1,18-20$ & 49.8 & 1.03 & 18.14 & 8.19 & 0.14 & 7.63 & 11.72 & 2.69 & 0.30 & 0.10 & 0.97 & 100.71 & 0.46 \\
\hline $15-1,12-14$ & 49.6 & 1.04 & 18.22 & 8.12 & 0.13 & 6.76 & 11.24 & 2.61 & 0.61 & 0.13 & 1.96 & 100.42 & 0.42 \\
\hline
\end{tabular}

$\mathrm{a}_{\mathrm{LOI}}=$ loss on ignition. 


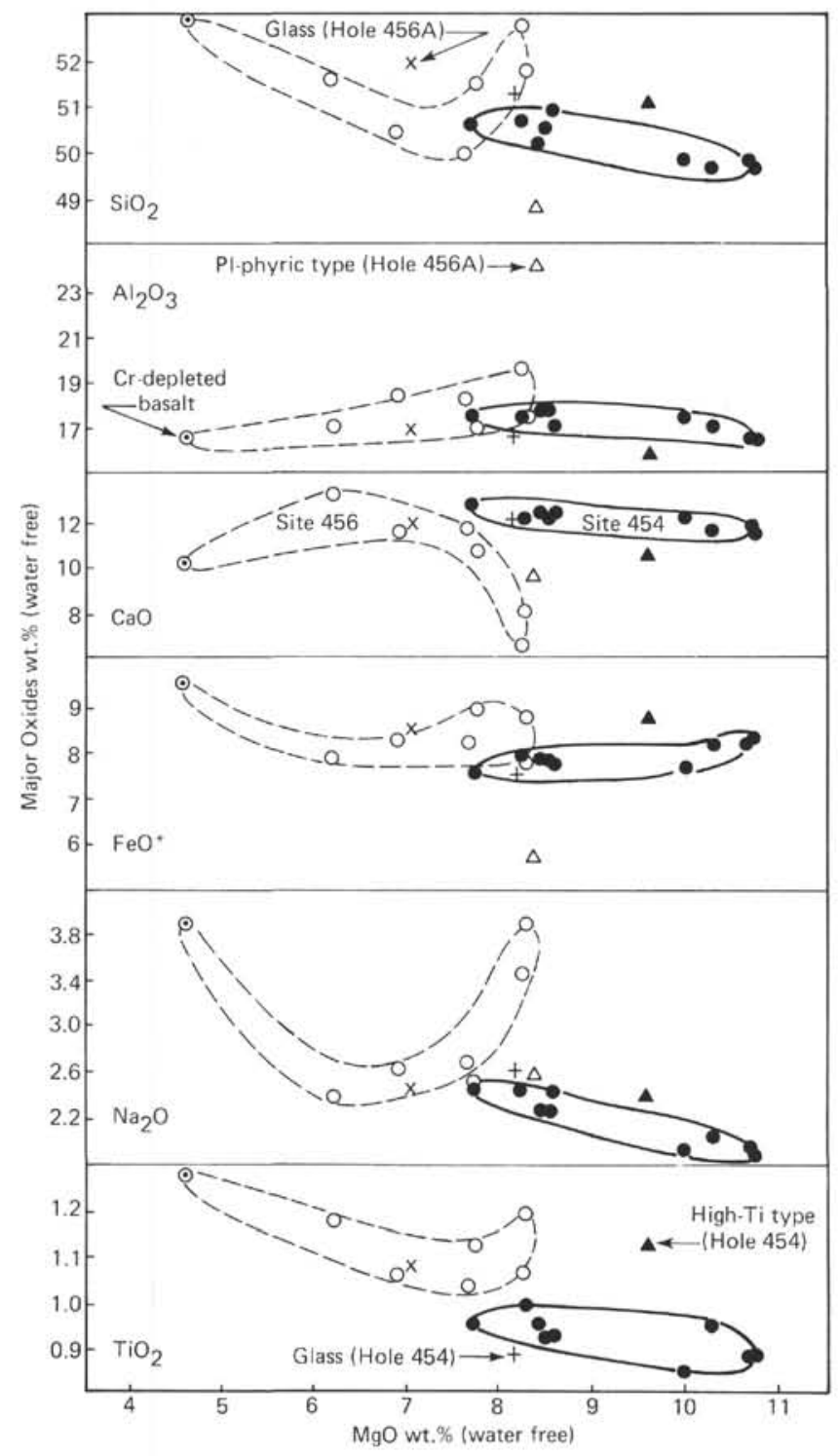

Figure 2. $\mathrm{MgO}$ variation diagram for Mariana Trough basalts.

duced by mixing of the evolved and more primitive magmas at the subcrustal magma chambers (Rhodes et al., 1979).

On $\mathrm{MgO}$ variation diagrams (Fig. 2) the Site 456 rocks form scattered plots, which can hardly be regarded as a continuation of the trend for Site 454. The intensive alteration of these rocks, noted petrograph- ically, is evident also from high ignition losses and high $\mathrm{Fe}_{2} \mathrm{O}_{3} / \mathrm{FeO}$ ratios (Table 3). This may be responsible for much of the compositional variation at the site, but still there is a considerable difference in composition between basalts at Sites 454 and 456 that must be magmatic in origin. The primary difference seems to be that the Site 456 lavas are more differentiated, as both chemical and petrographic characteristics suggest. Geochemically (Table 5) they do not deviate sharply from certain evolved MORB, except for one sample (456A-14-1, 5-8 $\mathrm{cm}$ ) which has extremely low $\mathrm{Cr}$ and $\mathrm{Ni}$ contents. Wood and co-authors (this volume) noted several more samples of similar geochemistry in Hole 456A. Both these elements are almost immobile in the course of alteration; therefore their low concentrations indicate that the relevant rocks are island arc, not ocean floor lavas.

\section{IGNEOUS SERIES OF THE MARIANA FORE-ARC SEGMENT: SITES 458 AND 459}

Site 458 is approximately in the middle of the outer fore-arc segment, near the large gravity anomaly complicating the geophysical character of this area of the Mariana island arc system (see site report, this volume). Acoustic basement here underlay early Oligocene sediments with abundant volcaniclastic material. Five lithologic units, within a 209-meter-thick igneous section, have a principal boundary between Units 3 and 4 (below Core 458-40). The upper portion consists of unusual rock types which I call "boninite series," since they have certain textural and mineralogical features first observed in boninites from the Bonin Islands. Below Unit 3 such rocks are interbedded with island arc tholeiites, which will be described together with similar rocks from Site 459.

Site 459 is adjacent to the Mariana Trench slope break. The 132.5-meter-thick igneous section penetrated in Hole $459 \mathrm{~B}$ is older than late Eocene and consists of basalts and andesites with island arc tholeiite affinities. There were no boninite rock types recovered among them, although we found a fragment of altered boninitic rock in Hole 460, much deeper on the trench slope, together with other rock debris in disturbed sedimentary sequences.

\section{The Boninite Series}

Rocks of unusual composition in Hole 458 form several massive lava flows, caped and interbedded with pillow lavas. Nearly all these rocks have undergone intensive alteration, which resulted in various secondary

Table 4. Microprobe analyses of glasses and minerals from Mariana Trough basalts.

\begin{tabular}{|c|c|c|c|c|c|c|c|c|c|c|c|}
\hline $\begin{array}{c}\text { Sample } \\
\text { (interval in } \mathrm{cm} \text { ) }\end{array}$ & $\mathrm{SiO}_{2}$ & $\mathrm{TiO}_{2}$ & $\mathrm{Al}_{2} \mathrm{O}_{3}$ & $\mathrm{FeO} *$ & $\mathrm{MgO}$ & $\mathrm{CaO}$ & $\mathrm{Na}_{2} \mathrm{O}$ & $\mathrm{K}_{2} \mathrm{O}$ & $\mathrm{H}_{2} \mathrm{O}^{+}$ & Total & Nomenclature \\
\hline $454-8-1,17-21$ & 50.91 & 0.86 & 16.36 & 7.34 & 8.06 & 12.01 & 2.61 & 0.21 & 1.58 & 99.96 & Fresh brown glass \\
\hline $456 \mathrm{~A}-13-1,17$ & 51.01 & 1.05 & 16.58 & 8.37 & 6.95 & 11.49 & 2.50 & 0.28 & 1.44 & 99.67 & Fresh brown glass \\
\hline $454-8-1,17-21$ & 41.21 & - & - & 11.67 & 46.60 & 0.28 & - & - & - & 99.76 & $\begin{array}{l}\text { Olivine microphenocryst } \\
\text { (Fo87.6) }\end{array}$ \\
\hline $454-5-4,12-14$ & 40.72 & - & - & 12.40 & 46.51 & 0.25 & - & - & - & 99.80 & Zoned olivine crystal: \\
\hline $454-5-4,12-14$ & 38.34 & - & - & 28.53 & 32.21 & 0.26 & - & - & - & 99.34 & $\begin{array}{l}\text { core: Fo87.0; } \\
\text { rim: Fo } 72.5\end{array}$ \\
\hline $454-5-4,12-14$ & 50.47 & 1.00 & 3.74 & 8.10 & 14.95 & 21.94 & 0.26 & 0.01 & - & 100.47 & Groundmass pyroxene \\
\hline $454-5-4,12-14$ & 52.51 & 0.05 & 29.94 & 0.48 & 0.22 & 13.51 & 2.45 & 0.05 & - & 99.21 & Plagioclase lath An75 \\
\hline $456-12-1,6-9$ & 48.60 & 0.02 & 32.57 & 0.36 & 0.15 & 16.45 & 1.52 & - & - & 99.67 & $\begin{array}{l}\text { Plagioclase phenocryst } \\
\text { An86 }\end{array}$ \\
\hline
\end{tabular}


Table 5. Trace element analyses of Mariana Trough basalts, Sites 454 and 456.

\begin{tabular}{|c|c|c|c|c|c|c|c|c|c|c|c|}
\hline $\begin{array}{c}\text { Samplc } \\
\text { (interval in } \mathrm{cm} \text { ) }\end{array}$ & $\mathrm{Rb}$ & $\mathrm{Li}$ & Sr & $\mathrm{Ba}$ & $\mathrm{Zr}$ & $\mathrm{Y}$ & $\mathrm{Cr}$ & $\mathrm{Ni}$ & $\mathrm{Co}$ & V & $\mathrm{Cu}$ \\
\hline \multicolumn{12}{|c|}{ Hole 454A } \\
\hline $5-1,13-15$ & 10.7 & 22.0 & 183 & 25 & 62 & 21 & 340 & 133 & 31 & 121 & 51 \\
\hline $5-2,43-45$ & 3.1 & 5.6 & 191 & 28 & 68 & 25 & 236 & 63 & 27 & 97 & 58 \\
\hline $5-3,105-107$ & 6.8 & 6.0 & 205 & 40 & 58 & 23 & 244 & 90 & 32 & 113 & 78 \\
\hline $5-4,12-14$ & 2.6 & 6.2 & 154 & 42 & 54 & 17 & 387 & 202 & 44 & 166 & 40 \\
\hline $6-2,99-101$ & 4.9 & 2.2 & 137 & 42 & 66 & 25 & 429 & 220 & 31 & 109 & 52 \\
\hline $6, \mathrm{CC}, 34-36$ & 1.3 & 5.9 & 206 & 36 & 56 & 21 & 268 & 80 & 30 & 89 & 54 \\
\hline $8-1,17-21$ & 8.3 & 3.8 & 167 & 22 & 59 & 16 & 516 & 270 & 39 & 155 & 50 \\
\hline $10-1,15-18$ & 8.8 & 5.3 & 157 & 38 & 57 & 17 & 458 & 236 & 36 & 126 & 58 \\
\hline $11-4,72-74$ & 1.8 & 4.1 & 220 & 55 & 60 & 24 & 331 & 140 & 34 & 135 & 43 \\
\hline $16-1,52-55$ & 7.8 & 4.5 & 179 & 80 & 80 & 28 & 394 & 250 & 36 & 177 & 48 \\
\hline \multicolumn{12}{|c|}{ Hole 456} \\
\hline $16-1,23-25$ & 1.9 & 5.0 & 183 & 60 & 76 & 24 & 250 & 88 & 41 & 121 & 37 \\
\hline $16-1,76-77$ & 3.8 & 31.0 & 394 & 83 & 80 & 27 & 270 & 71 & 39 & 112 & 50 \\
\hline $16-2,106-109$ & 4.5 & 3.7 & 226 & 20 & 70 & 26 & 262 & 84 & 24 & 79 & 40 \\
\hline \multicolumn{12}{|c|}{ Hole 456A } \\
\hline $12-1,6-9$ & 1.8 & 2.2 & 211 & 44 & 61 & 18 & 278 & 84 & 24 & 64 & 39 \\
\hline $13-1,17-19$ & 1.9 & 31.2 & 283 & 80 & 64 & 25 & 265 & 67 & 35 & 167 & 75 \\
\hline $14-1,5-8$ & 12.5 & 4.8 & 293 & 125 & 86 & 24 & 19 & 15 & 22 & 246 & 69 \\
\hline $14-1,18-20$ & 5.6 & 4.4 & 265 & 40 & 65 & 23 & 224 & 52 & 28 & 92 & 63 \\
\hline $15-1,12-14$ & 9.1 & 5.8 & 269 & 90 & 68 & 22 & 153 & 39 & 29 & 148 & 48 \\
\hline
\end{tabular}

mineral assemblages including several groups of clay minerals, zeolites, carbonate, minor quartz, and $\mathrm{Fe}$ hydroxides. Systematically increasing with depth, the degree of alteration depends as well on rock textures and mineralogy. In general the massive coarse-grained flows are less altered than pillow lavas, although the latter sometimes preserve entirely fresh fragments of glassy pillow rinds. Fifteen analyzed samples belong to three petrographic groups.

The first group includes five samples of glassy pillow rinds. The rocks, lacking plagioclase and hyalopilitic in texture, contain ortho- and clinopyroxenes as crystalline phases in a light colored glass with low refractive index $(n=1.561)$. Complex zonation, intergrowths, and twinning are characteristic features of pyroxene microphenocrysts, which are accompanied by plentiful microlites. Rare euhedral bronzite phenocrysts (up to $3 \mathrm{~mm}$ ) with chromite inclusions were observed in Sample $458-45-2,36-40$. This group in particular indicates most clearly the boninite affinity of the volcanic series under consideration.

Samples selected from pillow interiors differ from glassy rinds mineralogically and form another petrographic group. Glass is devitrified and altered; plumose aggregates of plagioclase appear in addition to pyroxenes, which are intensively replaced by clay minerals. Everywhere along the section, these rocks are the most altered varieties.

The third group encompasses rocks from the massive flow interiors. These are intersertal to holocrystalline fine- or medium-grained rocks with well-developed plagioclase laths. Orthopyroxenes are rare and always rimmed by zoned clinopyroxenes. The latter remain abundant and in general are more idiomorphic than plagioclase. The matrix is either devitrified glass or feldspar-quartz-magnetite intergrowths.

Analytical data on the samples and their constituents are presented in Tables 6,7 , and 8 . Boninites are glassy olivine-bronzite lavas lacking plagioclase, which are generally andesitic in composition, and depleted in incompatible elements, but enriched in $\mathrm{Cr}$ and $\mathrm{Ni}$. (e.g., see Kuroda and Shiraki, 1975). Although Site 458 rocks are olivine-free and may contain plagioclase, they are related to boninites by the presence of an extended pyroxene series (from bronzite, through pigeonite, to subcalcic and calcic augites, Table 8 ). The andesitic level of $\mathrm{SiO}_{2}$ in these rocks together with high $\mathrm{MgO}$ but low $\mathrm{TiO}_{2}$ content is also consistent with the boninite characteristics (Table 6). The geochemical data (Table 7) demonstrate the required depletion in a series of trace elements parallel to high $\mathrm{Cr}$ and $\mathrm{Ni}$ concentrations.

The Harker variation diagram (Fig. 3) shows that glassy pillow rinds and massive flow rocks are slightly different in composition. The higher $\mathrm{Al}_{2} \mathrm{O}_{3}$ but lower $\mathrm{MgO}$ content in the massive flow rocks, and the similar level of $\mathrm{SiO}_{2}$ concentrations in both groups, apparently are due to high-Mg pyroxene fractionation. Samples from pillow interiors are distinguished from other rock types by their depletion in $\mathrm{SiO}_{2}$ and $\mathrm{CaO}$, which was probably produced by the strong alteration of these

Table 6. Major element analyses of the "boninite series," Mariana fore-arc Hole 458.

\begin{tabular}{|c|c|c|c|c|c|c|c|c|c|c|c|c|c|}
\hline $\begin{array}{c}\text { Sample } \\
\text { (interval in } \mathrm{cm} \text { ) }\end{array}$ & $\mathrm{SiO}_{2}$ & $\mathrm{TiO}_{2}$ & $\mathrm{Al}_{2} \mathrm{O}_{3}$ & $\mathrm{FeO} *$ & $\mathrm{MnO}$ & $\mathrm{MgO}$ & $\mathrm{CaO}$ & $\mathrm{Na}_{2} \mathrm{O}$ & $\mathrm{K}_{2} \mathrm{O}$ & $\mathrm{P}_{2} \mathrm{O}_{5}$ & $\mathrm{LOI}^{\mathrm{a}}$ & Total & $\begin{array}{c}\mathrm{Fe}_{2} \mathrm{O}_{3} / \\
\mathrm{FeO}\end{array}$ \\
\hline \multicolumn{14}{|c|}{ Glassy pillow rinds } \\
\hline $28-1,139-141$ & 56.0 & 0.26 & 14.60 & 7.81 & 0.14 & 6.85 & 10.17 & 1.63 & 0.37 & 0.06 & 2.54 & 100.43 & 0.17 \\
\hline $28-1,26-29$ & 56.3 & 0.28 & 14.78 & 7.92 & 0.14 & 7.18 & 9.99 & 1.70 & 0.45 & 0.06 & 1.96 & 100.76 & 0.16 \\
\hline $31-1,75-78$ & 53.2 & 0.27 & 14.23 & 8.11 & 0.15 & 7.25 & 9.52 & 1.92 & 0.67 & 0.04 & 5.43 & 100.79 & 0.39 \\
\hline $39-1,11-15$ & 54.4 & 0.27 & 14.21 & 8.07 & 0.16 & 7.43 & 9.60 & 1.93 & 0.45 & 0.06 & 3.90 & 100.48 & 0.18 \\
\hline $45-2,36-40$ & 51.8 & 0.46 & 13.94 & 8.45 & 0.15 & 7.88 & 8.20 & 2.22 & 0.56 & 0.05 & 6.65 & 100,36 & 0.49 \\
\hline \multicolumn{14}{|c|}{ Altered pillow interiors } \\
\hline $29-2,30-32$ & 50.3 & 0.31 & 16.30 & 8.16 & 0.11 & 7.95 & 8.85 & 2.47 & 0.62 & 0.05 & 5.40 & 100.52 & 1.13 \\
\hline $30-1,5-7$ & 50.5 & 0.30 & 16.28 & 7.90 & 0.10 & 7.31 & 8.90 & 2.01 & 1.31 & 0.04 & 6.06 & 100.71 & 1.37 \\
\hline $36-1,125-128$ & 50.5 & 0.30 & 16.51 & 8.10 & 0.12 & 6.90 & 7.85 & 2.42 & 0.91 & 0.06 & 6.67 & 100.34 & 1.86 \\
\hline $40-1,8-10$ & 50.6 & 0.32 & 16.11 & 8.20 & 0.10 & 7.05 & 7.47 & 2.32 & 1.07 & 0.04 & 6.91 & 100.19 & 1.51 \\
\hline $40-2,106-109$ & 50.1 & 0.30 & 16.33 & 8.25 & 0.08 & 7.07 & 7.80 & 2.33 & 0.90 & 0.05 & 6.80 & 100.01 & 1.71 \\
\hline \multicolumn{14}{|c|}{ Massive flow interiors } \\
\hline $32-1,128-131$ & 56.3 & 0.28 & 15.55 & 7.85 & 0.11 & 5.46 & 10.54 & 2.39 & 0.74 & 0.07 & 1.21 & 100.50 & 1.02 \\
\hline $32-4,14-17$ & 56.2 & 0.29 & 15.62 & 8.06 & 0.11 & 5.14 & 10.39 & 2.21 & 0.85 & 0.07 & 1.43 & 100.37 & 0.92 \\
\hline $33-2,23-25$ & 56.3 & 0.29 & 14.85 & 7.75 & 0.12 & 6.72 & 10.22 & 2.01 & 0.41 & 0.07 & 1.70 & 100.44 & 0.53 \\
\hline $34-1,115-117$ & 55.8 & 0.31 & 15.75 & 7.75 & 0.12 & 5.41 & 10.83 & 2.24 & 0.70 & 0.08 & 1.55 & 100.54 & 0.80 \\
\hline $38-1,27-32$ & 55.4 & 0.40 & 16.25 & 8.03 & 0.13 & 5.44 & 10.48 & 2.00 & 0.89 & 0.05 & 1.85 & 100.92 & 0.74 \\
\hline
\end{tabular}

${ }^{\mathrm{a}} \mathrm{LOI}=$ loss on ignition. 
Table 7. Trace element analyses of the "boninite series," Mariana fore-arc Hole 458

\begin{tabular}{|c|c|c|c|c|c|c|c|c|c|c|c|}
\hline $\begin{array}{c}\text { Sample } \\
\text { (interval in } \mathrm{cm} \text { ) }\end{array}$ & $\mathrm{Rb}$ & $\mathrm{Li}$ & $\mathrm{Sr}$ & $\mathrm{Ba}$ & $\mathrm{Zr}$ & $\mathrm{Y}$ & $\mathrm{Cr}$ & $\mathrm{Ni}$ & $\mathrm{Co}$ & v & $\mathrm{Cu}$ \\
\hline \multicolumn{12}{|c|}{ Glassy pillow rinds } \\
\hline $28-1,139-141$ & 7.8 & 13.1 & 81 & 26 & 19 & 5.7 & 228 & 71 & 48 & 200 & 55 \\
\hline $28-1,26-29$ & 8.2 & 12.1 & 87 & 30 & 24 & 5.6 & 230 & 70 & 45 & 210 & 70 \\
\hline $31-1,75-78$ & 7.8 & 13.1 & 115 & 32 & 29 & 6.3 & 196 & 73 & 48 & 180 & 75 \\
\hline $39-1,11-15$ & 7.9 & 16.0 & 75 & 25 & 26 & 11.5 & 207 & 76 & 52 & 191 & 78 \\
\hline $45-2,36-40$ & 4.7 & 21.9 & 68 & 21 & 43 & 10.5 & 219 & 88 & 55 & 262 & 61 \\
\hline \multicolumn{12}{|c|}{ Altered pillow interiors } \\
\hline $29-2,30-32$ & 0.8 & 12.1 & 123 & 18 & 30 & 5.0 & 208 & 62 & 48 & 250 & 33 \\
\hline $30-1,5-7$ & 4.4 & 10.9 & 126 & 24 & 29 & 6.3 & 242 & 69 & 36 & 137 & 26 \\
\hline $36-1,125-128$ & 4.2 & 25.0 & 134 & 20 & 27 & 5.8 & 238 & 87 & 44 & 178 & 41 \\
\hline $40-1,8-10$ & 4.7 & 23.2 & 142 & 20 & 34 & 6.2 & 310 & 82 & 42 & 224 & 30 \\
\hline $40-2,106-109$ & 4.3 & 17.7 & 106 & 17 & 29 & 5.0 & 267 & 77 & 39 & 146 & 33 \\
\hline \multicolumn{12}{|c|}{ Massive flow interiors } \\
\hline $32-1,128-131$ & 52.5 & 11.6 & 125 & 40 & 30 & 5.6 & 197 & 55 & 42 & 296 & 28 \\
\hline $32-4,14-17$ & 47.5 & 10.0 & 151 & 57 & 31 & 6.6 & 200 & 46 & 37 & 192 & 19 \\
\hline $33-2,23-25$ & 23.9 & 6.9 & 153 & 35 & 27 & 5.4 & 236 & 63 & 43 & 243 & 29 \\
\hline $34-1,115-117$ & 20.2 & 15.4 & 139 & 46 & 30 & 7.0 & 250 & 49 & 37 & 198 & 19 \\
\hline $38-1,27-32$ & 16.3 & 16.9 & 145 & 42 & 34 & 8.0 & 290 & 60 & 33 & 190 & 29 \\
\hline
\end{tabular}

rock types. It is compensated by the higher contents of $\mathrm{Al}_{2} \mathrm{O}_{3}, \mathrm{FeO}^{*}$ and $\mathrm{Na}_{2} \mathrm{O}$.

\section{The Island Arc Tholeiite Series}

Rocks of island arc tholeiite affinity which forming the Site 459 basement section also occur in the lower part of Hole 458. The lithology indicates that they erupted in the form of massive and pillow lava flows or were intruded as sills (Unit 3, Site 459; see site chapters).

The rocks at both sites are intensively altered. In order of abundance the secondary products are various groups of clay minerals, zeolites, carbonate, and $\mathrm{Fe}$ hydroxides. These minerals replace the rock mesostasis and primary pyroxenes or fill veins and vesicles. The degree of alteration is variable, depending on the rock textures, but in general it increases with depth.

The predominant basaltic composition at both sites is attributable to massive and pillow lava flows when the sill, intruding the Site 459 sequence, is andesitic. Basalt samples (one from Hole 458 and eight from Hole 459B) are fine-grained aphyric to sparsely phyric rocks, which are hyalo-ophitic, hyalopilitic, and intersertal in texture. Occasional microphenocrysts of plagioclase, sometimes in association with scarce pseudomorphs after clinopyroxene, comprise no more than 3 to $5 \%$ of the rock by volume. In the groundmass, plagioclase predominates over clinopyroxene and is always better preserved. Fairly abundant opaque grains and crystallites are concentrated in mesostasis. Many of these rocks are highly vesicular, even scoriaceous, but their porosity is usually disguised because the vesicles are filled with secondary minerals.
The aphyric andesite sill has fine-grained marginal zones (Samples 459B-65-1, 47-50 cm and 459B-69-1, 9-12 cm) and a coarser-grained internal portion of subophitic texture (Samples 459B-66-1, 77-80 cm; 459B66-1, 95-100 cm; 459B-67-1, 71-73 cm; and 459B-69-3, $48-50 \mathrm{~cm})$. The mineral components of the sill are plagioclase and pyroxene, cemented by patchy mesostasis. The mesostasis, being glassy at the cooling boundaries, occurs as micrographic intergrowths of quartz and feldspar in the sill interiors. Small euhedral or skeletal crystals of Fe-Ti oxides are associated with patches of the mesostasis. The sill rocks are much less vesicular than the host basalts.

According to analytical data (Tables 9 and 10) the basalts and andesites under consideration belong to the arc tholeiite suite, as indicated by the increasing $\mathrm{FeO}^{*}$ contents in rocks with higher $\mathrm{SiO}_{2}$ contents (Fig. 4). The uppermost unit in Hole 459 differs from other basalts in higher $\mathrm{CaO}$ and $\mathrm{MgO}$ but lower $\mathrm{Al}_{2} \mathrm{O}_{3}$ and $\mathrm{Na}_{2} \mathrm{O}$ content (Fig. 4). These characteristics, as well as parallel enrichment of upper lavas in $\mathrm{Cr}$ and $\mathrm{Ni}$ (Table 10), may be ascribed to the plagioclase fractionation in the ascending magma column. Compositional variations in andesites (Fig. 4) may indicate a small-scale pyroxene fractionation after sill emplacement.

\section{DISCUSSION}

A thorough consideration of the petrogenetic and tectonic implications of Leg 60 drilling results is beyond the scope of this chapter. Several intriguing facts are nevertheless worthy of a brief summary.

The metagabbro-metabasalt breccia deposited at the bottom of a narrow sediment pond about $10 \mathrm{~km}$ east of the eastern edge of the West Mariana Ridge derives from an island arc, as indicated by the calc-alkaline affinities of the volcanic clasts. Generally high in $\mathrm{Al}_{2} \mathrm{O}_{3}$, $\mathrm{Sr}$, and $\mathrm{Ba}$ values, these rocks are similar to the upper Miocene calc-alkaline volcaniclastic debris from Hole 451 in an adjacent area of the West Mariana Ridge (Wood et al., in press) but contrast in this respect with the older arc tholeiites from the Palau-Kyushu Ridge and the southern Mariana Islands (Scott, in press; Stark, 1963). The geophysical survey of Site 451 (Langseth and Mrozowski, in press) indicates that in this area of the West Mariana Ridge the $1.5-\mathrm{km}$-thick arc basement layer with an average velocity of $4 \mathrm{~km} / \mathrm{s}$ overlies a layer with a velocity greater than $5 \mathrm{~km} / \mathrm{s}$. These facts suggest that the metavolcanic rocks in breccia may have derived from the deepest portion of the upper Miocene island arc sequence and that metamorphosed and partly

Table 8. Microprobe analyses of glass and minerals from the "boninite series," Hole 458.

\begin{tabular}{|c|c|c|c|c|c|c|c|c|c|c|c|}
\hline $\begin{array}{c}\text { Sample } \\
\text { (interval in } \mathrm{cm} \text { ) }\end{array}$ & $\mathrm{SiO}_{2}$ & $\mathrm{TiO}_{2}$ & $\mathrm{Al}_{2} \mathrm{O}_{3}$ & $\mathrm{FeO}^{*}$ & $\mathrm{MgO}$ & $\mathrm{CaO}$ & $\mathrm{Na}_{2} \mathrm{O}$ & $\mathrm{K}_{2} \mathrm{O}$ & $\mathrm{H}_{2} \mathrm{O}^{+}$ & Total & Nomenclature \\
\hline $39-1,11-15$ & 56.87 & 0.29 & 13.86 & 7.67 & 6.62 & 9.80 & 1.80 & 0.40 & 2.25 & 99.56 & Fresh light-colored glass \\
\hline $45-2,36-40$ & 56.95 & 0.06 & 0.75 & 8.76 & 31.27 & 1.52 & 0.02 & 0.01 & - & 99.65 & Bronzite phenocryst \\
\hline $39-1,11-15$ & 56.60 & 0.04 & 1.03 & 10.09 & 28.35 & 3.29 & 0.04 & 0.02 & - & 99.53 & Pigeonite microlite \\
\hline $30-1,5-7$ & 53.06 & 0.11 & 2.43 & 6.42 & 19.75 & 18.41 & 0.14 & 0.03 & - & 100.22 & Zoned augite \\
\hline $30-1,5-7$ & 53.34 & 0.07 & 2.56 & 8.66 & 19.52 & 16.05 & 0.11 & 0.03 & - & 100.62 & microphenocryst \\
\hline $33-2,23-25$ & 52.15 & 0.27 & 2.75 & 8.65 & 16.38 & 19.76 & 0.15 & 0.04 & - & 100.16 & Zoned augite crystal \\
\hline $33-2,23-25$ & 51.84 & 0.21 & 2.38 & 12.22 & 14.18 & 19.23 & 0.11 & 0.03 & - & 100.68 & in the groundmass \\
\hline $33-2,23-25$ & 51.61 & 0.05 & 30.99 & 0.68 & 0.21 & 14.31 & 2.02 & 0.05 & - & 99.85 & Plagioclase lath (An80) \\
\hline
\end{tabular}




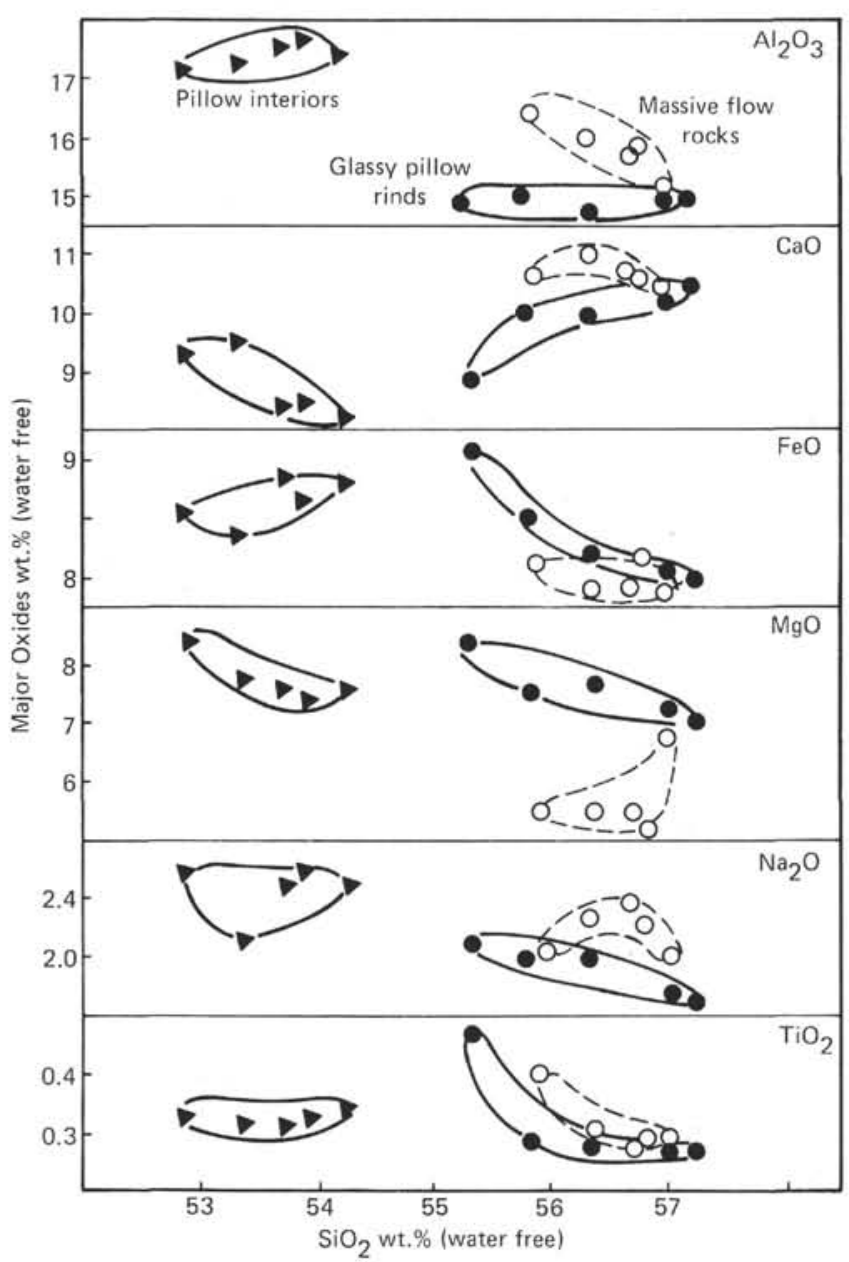

Figure 3. Harker variation diagram for the boninite rock series.

tectonized gabbroic materials probably belong to the more dense layer below it.

A catastrophic rock fall, resulting in breccia deposition, took place at Site 453 before pelagic sedimentation, about $5 \mathrm{Ma}$. At that time all arc volcanic activity had ceased (Scott et al., in press), and the sundering of the West Mariana arc must have occurred. This was the ultimate tectonic cause of breccia formation. At present, it is uncertain whether the breccia was deposited on the young basaltic basement or directly covered older lower crustal rocks, exposed by the arc rifting. This question, pertinent to the subjects of back-arc magmatism and tectonics, remains to be answered by the future drilling.

The petrologic characteristics of the back-arc basin basalts present another side of this compelling question. Hart et al. (1972) noted the higher contents of certain trace elements in the Mariana Trough basalts relative to normal MORB but assigned a similar (mantle) source for both magma types, diverging owing to a difference in the degree of partial melting. Garcia and co-authors (1979) found that the Mariana Trough basaltic glasses contain five times more $\mathrm{H}_{2} \mathrm{O}$ and nearly twice as much $\mathrm{CO}_{2}$ as compared to Mid-Atlantic Ridge pillow basalt rims. Two glass samples in the present study also have a high water content. It is attractive to explain this peculiarity as a by-product of dehydration of the subducted oceanic lithosphere, contaminating the back-arc magmas by volatile components. If this is the case, the higher concentrations of certain mobile trace elements in the trough basalts seem reasonable; one would expect, however, a parallel influence on their isotopic composition, which has not been borne out by available data (Meijer, 1976). Nor does this suggested mechanism affect the mineralogy and crystallization sequence of known Mariana Trough basalts. Because of these contradictions, this question also remains open for discussion-especially since some of geochemical anomalies observed in the drilled basalts could have been due to secondary rock alteration.

With respect to immobile trace elements such as $\mathrm{Ti}$, $\mathrm{Zr}, \mathrm{Y}$, and $\mathrm{Cr}$, the Mariana Trough basalts are generally similar to MORB. On a series of discrimination diagrams (Figs. 5-7), they plot constantly in the MORB fields, except for one sample that is highly depleted in $\mathrm{Cr}$ and $\mathrm{Ni}$ (Fig. 5; Table 5). On the one hand, this very rock (like similar rocks, studied by Wood et al., (this volume) has the highest $\mathrm{FeO}^{*} / \mathrm{MgO}$ ratio (Fig. 2) and therefore may be considered as an evolved type of basalt, depleted in $\mathrm{Cr}$ and $\mathrm{Ni}$ owing to strong fractionation of $\mathrm{Cr}$-spinel and $\mathrm{Fe}-\mathrm{Mg}$ minerals. This is consistent with the high Ti, Zr, and Y values (e.g., Figs. 6 and 7), inasmuch as all these elements had to be concentrated in the course of fractionation. This explanation, however,

Table 9. Major element analyses of the island arc tholeiite series, Mariana fore-arc Sites 458 and 459.

\begin{tabular}{|c|c|c|c|c|c|c|c|c|c|c|c|c|c|}
\hline $\begin{array}{c}\text { Sample } \\
\text { (interval in } \mathrm{cm} \text { ) }\end{array}$ & $\mathrm{SiO}_{2}$ & $\mathrm{TiO}_{2}$ & $\mathrm{Al}_{2} \mathrm{O}_{3}$ & $\mathrm{FeO}^{*}$ & $\mathrm{MnO}$ & $\mathrm{MgO}$ & $\mathrm{CaO}$ & $\mathrm{Na}_{2} \mathrm{O}$ & $\mathrm{K}_{2} \mathrm{O}$ & $\mathrm{P}_{2} \mathrm{O}_{5}$ & $\mathrm{LOI}^{\mathrm{a}}$ & Total & $\begin{array}{c}\mathrm{Fe}_{2} \mathrm{O}_{3} / \\
\mathrm{FeO}\end{array}$ \\
\hline \multicolumn{14}{|c|}{ Hole 458} \\
\hline $47-2,19-23$ & 51.4 & 0.94 & 16.10 & 11.08 & 0.07 & 4.49 & 6.51 & 3.85 & 0.67 & 0.19 & 4.97 & 100.27 & 2.17 \\
\hline \multicolumn{14}{|c|}{ Hole 459B } \\
\hline $60-1,95-101$ & 50.6 & 0.74 & 15.70 & 9.99 & 0.13 & 5.40 & 11.18 & 3.09 & 0.45 & 0.10 & 2.10 & 99.22 & 1.08 \\
\hline $61-1,102-106$ & 50.0 & 0.68 & 14.87 & 9.23 & 0.13 & 6.28 & 11.42 & 2.66 & 0.33 & 0.07 & 3.81 & 98.98 & 0.93 \\
\hline $62-1,44-46$ & 51.3 & 0.63 & 15.31 & 9.11 & 0.14 & 6.23 & 11.53 & 2.65 & 0.44 & 0.08 & 1.95 & 99.37 & 0.83 \\
\hline $64-1,31-34$ & 49.5 & 0.70 & 17.15 & 9.20 & 0.10 & 6.27 & 8.66 & 3.54 & 0.75 & 0.11 & 3.16 & 99.14 & 1.18 \\
\hline $65-1,47-50$ & 56.1 & 0.94 & 14.86 & 10.40 & 0.17 & 3.13 & 7.54 & 3.59 & 0.41 & 0.11 & 3.10 & 100.32 & 1.25 \\
\hline $66-1,77-80$ & 55.8 & 0.95 & 13.90 & 10.80 & 0.14 & 3.99 & 7.86 & 3.45 & 0.57 & 0.10 & 2.31 & 99.87 & 1.67 \\
\hline $66-1,95-100$ & 55.4 & 0.87 & 14.97 & 10.38 & 0.13 & 3.83 & 7.57 & 3.54 & 0.99 & 0.12 & 2.98 & 100.78 & 1.95 \\
\hline $67-1,71-73$ & 53.7 & 0.97 & 15.57 & 10.44 & 0.13 & 3.58 & 8.02 & 3.46 & 0.99 & 0.10 & 2.62 & 99.58 & 1.28 \\
\hline $69-3,48-50$ & 50.2 & 0.71 & 17.10 & 9.28 & 0.13 & 5.49 & 9.24 & 3.47 & 0.32 & 0.09 & 4.24 & 100.27 & 1.80 \\
\hline $69-1,9-12$ & 55.1 & 0.60 & 14.70 & 10.02 & 0.13 & 5.86 & 5.92 & 3.74 & 0.27 & 0.08 & 3,48 & 99.90 & 1.25 \\
\hline $71-1,77-79$ & 50.7 & 1.10 & 16.60 & 10.70 & 0.14 & 4.00 & 8.14 & 3.75 & 0.37 & 0.11 & 3.87 & 99.48 & 0.86 \\
\hline $73-1,40-42$ & 51.5 & 1.01 & 16.20 & 10.42 & 0.11 & 3.73 & 8.83 & 3.75 & 0.75 & 0.11 & 2.94 & 99.35 & 1.17 \\
\hline $73-3,83-85$ & 51.4 & 0.94 & 16.51 & 10.53 & 0.10 & 3.84 & 8.00 & 4.00 & 0.46 & 0.13 & 3.54 & 99.45 & 1.11 \\
\hline
\end{tabular}

${ }^{\mathrm{a}} \mathrm{LOI}=$ loss on ignition. 
Table 10. Trace element analyses of the island arc tholeiite series, Mariana fore-arc Sites 458 and 459.

\begin{tabular}{|c|c|c|c|c|c|c|c|c|c|c|c|}
\hline $\begin{array}{c}\text { Sample } \\
\text { (interval in } \mathrm{cm} \text { ) }\end{array}$ & Ro & $\mathrm{Li}$ & $\mathrm{Sr}$ & $\mathrm{Ba}$ & $\mathrm{Zr}$ & $\mathrm{Y}$ & $\mathrm{Cr}$ & $\mathrm{Ni}$ & Co & V & $\mathrm{Cu}$ \\
\hline \multicolumn{12}{|c|}{ Hole 458} \\
\hline $47-2,19-23$ & 12.8 & 19.0 & 159 & 46 & 62 & 36 & 21 & 16 & 25 & 363 & 58 \\
\hline \multicolumn{12}{|c|}{ Hole 459B } \\
\hline $60-1,95-101$ & 18.6 & 11.1 & 142 & 36 & 43 & 23 & 184 & 49 & 30 & 277 & 55 \\
\hline $61-1,102-106$ & 18.1 & 13.4 & 118 & 34 & 43 & 16 & 211 & 52 & 40 & 350 & 99 \\
\hline $62-1,44-46$ & 10.1 & 18.2 & 150 & 30 & 40 & 17 & 178 & 48 & 35 & 158 & 30 \\
\hline $64-1,31-34$ & 6.2 & 7.1 & 145 & 31 & 39 & 21 & 68 & 40 & 29 & 218 & 26 \\
\hline $65-1,47-50$ & 9.7 & 9.7 & 95 & 62 & 55 & 23 & 16 & 24 & 24 & 243 & 97 \\
\hline $66-1,77-80$ & 27.5 & 30.0 & 129 & 30 & 54 & 24 & 15 & 18 & 33 & 305 & 34 \\
\hline $66-1,95-100$ & 21.6 & 26.7 & 160 & 36 & 45 & 21 & 17 & 20 & 34 & 194 & 29 \\
\hline $67-1,71-73$ & 17.8 & 11.4 & 110 & 38 & 50 & 21 & 15 & 25 & 28 & 282 & 34 \\
\hline $69-1,9-12$ & 10.4 & 5.2 & 134 & 26 & 37 & 20 & 26 & 28 & 28 & 221 & 43 \\
\hline $69-3,48-50$ & 9.6 & 16.5 & 159 & 44 & 38 & 24 & 22 & 21 & 29 & 225 & 95 \\
\hline $71-1,77-79$ & 5.3 & 16.8 & 132 & 41 & 62 & 34 & 13 & 11 & 24 & 266 & 46 \\
\hline $73-1,40-42$ & 17.4 & 9.0 & 137 & 52 & 61 & 30 & 16 & 11 & 23 & 271 & 42 \\
\hline $73-3,83-85$ & 13.5 & 4.4 & 122 & 33 & 57 & 37 & 16 & 12 & 24 & 190 & 27 \\
\hline
\end{tabular}

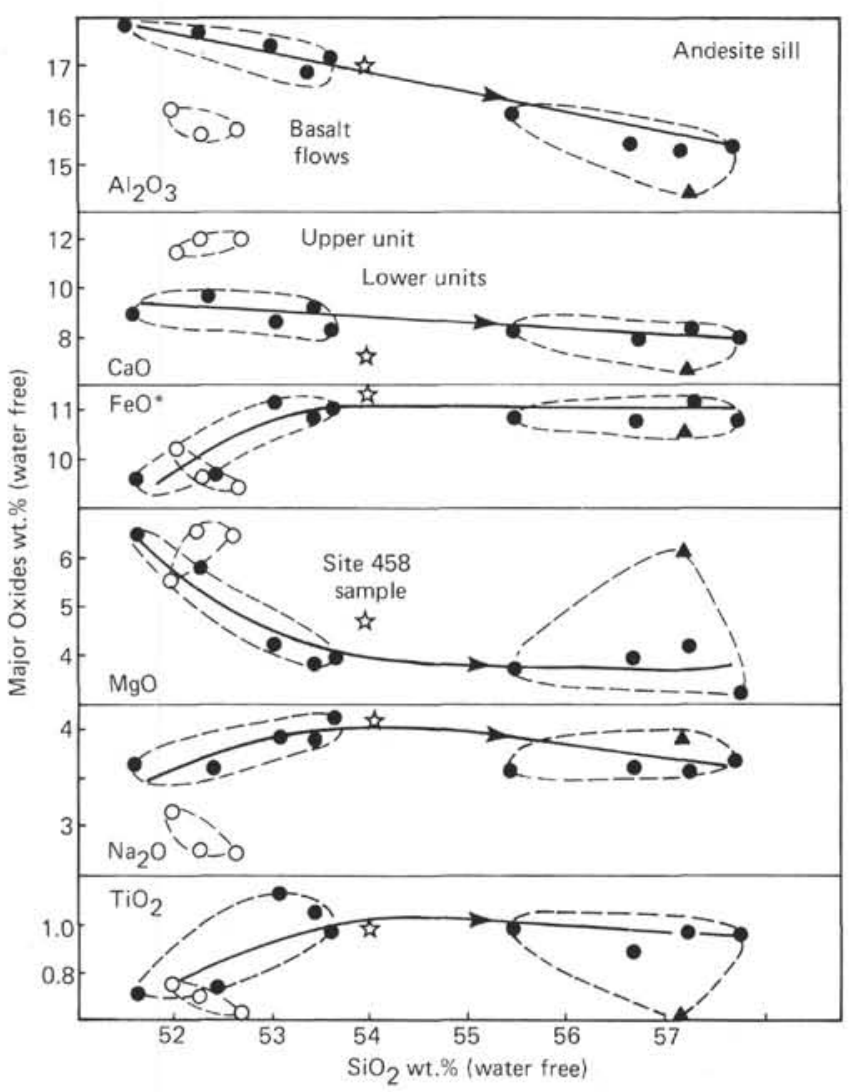

Figure 4. Harker variation diagram for Sites 458 and 459 arc tholeiite series.

remains doubtful, because this extent of $\mathrm{Cr}$ and $\mathrm{Ni}$ depletion has never been observed in the numerous MORB samples analyzed. Wood et al. (this volume) suggested that rocks of such geochemistry were produced by mixing of back-arc and island arc magmas. The recent period of volcanic activity on the Marianas, during which $\mathrm{Cr}$ - and $\mathrm{Ni}$-depleted lavas erupted, (Dixon and Batiza, 1979), began about $2 \mathrm{Ma}-$ i.e., close to the time of eruption of the Site 456 basalts. If the arguments presented by Wood and co-authors are valid, two possi- ble tectonic models emerge. If the spreading center in the Mariana Trough is west of Site 456, as suggested by many researchers, then the site position relative to the active volcanic arc had to remain fixed. In that case, arc magmatism, now restricted to a narrow zone, initially had a more diffuse character and was thus able to affect an area about $10 \mathrm{~km}$ away. The asymmetric spreading model also suggests that Site 456 rocks with calcalkaline affinities simply mark the former position of the arc, now shifted toward the east. Which of the models is true remains uncertain, although the first appears more likely at present.

One of the most interesting findings in the fore-arc region is the discovery of the boninite series, which, together with arc tholeiites, forms its acoustic basement. The petrology of arc volcanism has been discussed many times on the basis of different approaches and hardly needs additional speculation or comment. It is important to note only that all investigators who have studied boninites or related rocks (Kuroda and Shiraki, 1975; Shiraki et al., 1979; Sharaskin et al., 1980), including contributors to this volume, agree in different or somehow modified sources for arc tholeiites, on the one hand, and for boninites on the other. The coexistence of both magma types in space and time is a poorly understood phenomenon. Meijer and Youngblood (this volume) put forward the attractive idea, that the depletion of ultramafic source materials in incompatible trace elements necessary to produce boninites occurred in the course of previous intensive partial melting of arc tholeiite compositions from a mantle wedge above the subduction zone. The suggested sequence of events does fit the stratigraphy of the Site 458 basement section, but the explanation is not wholly satisfactory. In fact, eruption of arc tholeiite continued elsewhere on the inferred paleo-arc until the middle Oligocene (see Site 448 data in Kroenke, Scott, et al., in press)-i.e., after cessation of boninite volcanism.

Why did such magmas appear only during that period and never again? How were the unusual thermal conditions necessary to boninite production attained? What mechanism was responsible for the contrasting tectonophysical environments in a mantle wedge above the upper Eocene-Oligocene subduction zone? All these questions, unanswered at present, are vital indeed, since rocks with boninite geochemistry have erupted elsewhere on Earth during the Mesozoic and Paleozoic (Cameron et al., 1979; Sharaskin et al., 1980).

\section{ACKNOWLEDGMENTS}

I am grateful to I. A. Rostshina, E. N. Savinova, A. I. Lebedkova, L. V. Krigman, and E. M. Sedykh for their valuable assistance in analytical work. A. V. Sobolev was my competent guide in all microprobe analyses, and B. A. Rodnikov assisted all necessary technical operations. The study was funded by the USSR Academy of Sciences.

\section{REFERENCES}

Cameron, W. E., Nisbet, E. G., and Dietriich, V. J., 1979. Boninites, komatiites and ophiolitic basalts. Nature, 280:550-553.

Dixon, T. H., and Batiza, R., 1979. Petrology and chemistry of recent lavas in the Northern Marianas: Implications for the origin of island arc basalts. Contrib. Mineral. Petrol., 70:167-181. 
Garcia, M. O., Liu, N. W. K., and Muenow, D. W., 1979. Volatiles in submarine volcanic rocks from the Mariana Island arc and trough. Geochim. Cosmochim. Acta, 43:305-312.

Hart, S. R., Glassley, W. E., and Karig, D. E., 1972. Basalts and sea floor spreading behind the Mariana Island arc. Earth Planet. Sci. Lett., 15:12-18.

Kroenke, L., Scott, R., et al., in press. Site 448: Palau-Kyushu Ridge. In Kroenke, L., Scott, R. B., et al., Init. Repts. DSDP, 59: Washington (U.S. Govt. Printing Office), 111-320.

Kuroda, M., and Shiraki, K., 1975. Boninite and related rocks of Chichi-Jima, Bonin Islands. Rep. Fac. Sci. Shizuoka Univ., $10: 145-155$

Langseth, M. G., and Mrozowski, C. L., in press. Geophysical surveys for Leg 59 sites, DSDP. In Kroenke, L., Scott, R. B., et al., Init. Repts. DSDP, 59: Washington (U.S. Govt. Printing Office), 487-502.

Meijer, A., 1976. $\mathrm{Pb}$ and $\mathrm{Sr}$ isotopic data bearing on the origin of volcanic rocks from the Mariana island arc system. Bull. Geol. Soc. Am., 87:1358-1369.

Pearce, J. A., 1975. Basalt geochemistry used to investigate past tectonic environment on Cyprus. Tectonophysics, 25:41-68.

Rhodes, J. M., Dungan, M. A., Blanchard, D. P. et al., 1979. Magma mixing at mid-ocean ridges: Evidence from basalts drilled near $22^{\circ} \mathrm{N}$ on the Mid-Atlantic Ridge. Tectonophysics, 55:35-61.

Scott, R. B., in press. Petrology and geochemistry of volcanic units on the Palau-Kyushu Ridge, Site 448, DSDP Leg 59. In Kroenke, L.,
Scott, R. B., et al., Init. Repts. DSDP, 59: Washington (U.S. Govt. Printing Office), 681-692.

Scott, R. B., Kroenke, L., Zakariadze, G., et al., in press. Evolution of the South Philippine Sea: DSDP Leg 59 results. In Kroenke, L., Scott, R. B., et al., Init. Repts. DSDP, 59: Washington (U.S. Govt. Printing Office), 803-816.

Sharaskin, A. Ya., Dobretsov, N. L., and Sobolev, N. V., 1980. Marianites: The clinoenstatite bearing pillow lavas associated with ophislite assemblage of the Mariana Trench. In Panayiotou, A. (ㄷd.), Ophiolites: Proc. Int. Ophiolite Symp. Cyprus, pp. 473479.

Shiraki, K., Kuroda, N., and Urano, H., 1979. Clinoenstatite bearing boninite of Muko-Jima, Bonin Islands. J. Geol. Soc. Jpn., 85: 591-594.

Stark, J. T., 1963. Petrology of the volcanic rocks of Guam. Geol. Survey Prof. Pap. U.S., 403-C, p. 32.

Sun, S.-S., Nesbitt, R. W., and Sharaskin, A. Ya., 1979. Chemical characteristics of mid-ocean ridge basalts. Earth Planet. Sci. Lett., 44:119-138.

Wood, D. A., Mattey, D. P., Joron, J-L., et al., in press. A geochemical study of 17 selected samples from the basement cores recovered at Sites 447, 448, 449, 450, and 451, DSDP Leg 59. In Kroenke, L., Scott, R. B., et al., Init. Repts. DSDP, 59: Washington (U.S. Govt. Printing Office), 743-752.

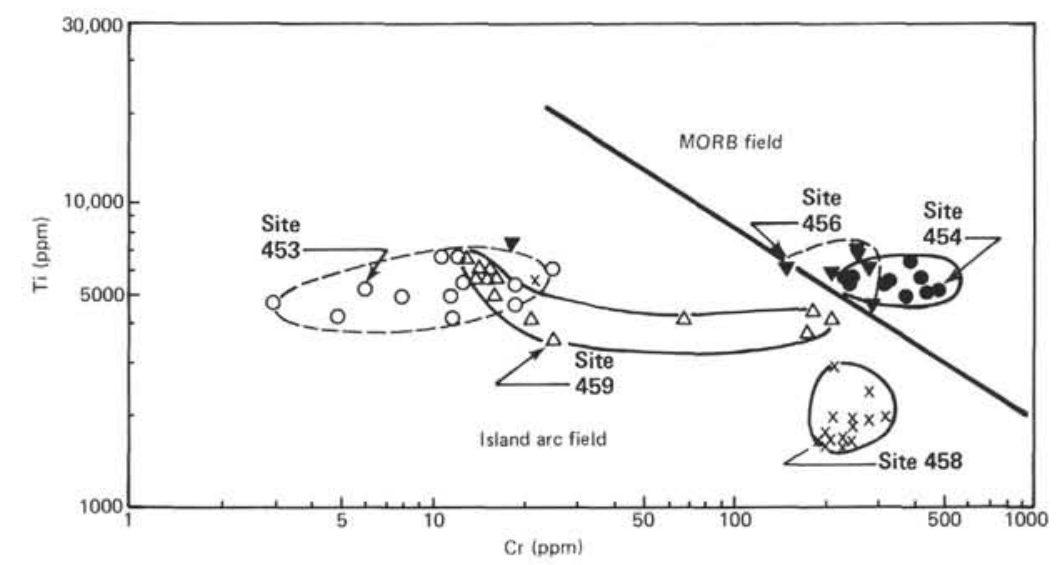

Figure 5. $\mathrm{Ti}$ vs. $\mathrm{Cr}$ diagram for back-arc basin and fore-arc rocks. (Subdivision line is after Pearce [1975].)

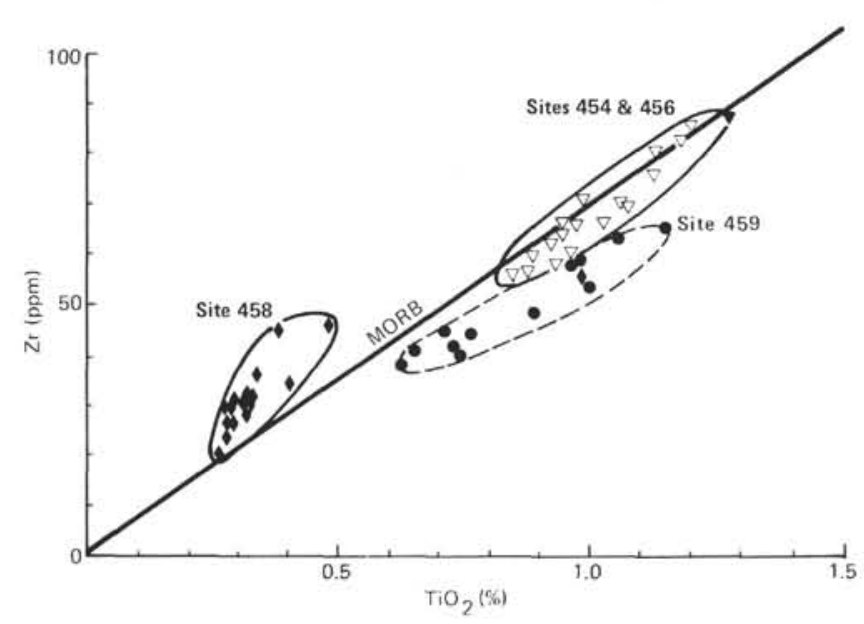

Figure 6. $\mathrm{Zr}$ vs. $\mathrm{TiO}_{2}$ diagram for back-arc basin and fore-arc rocks.

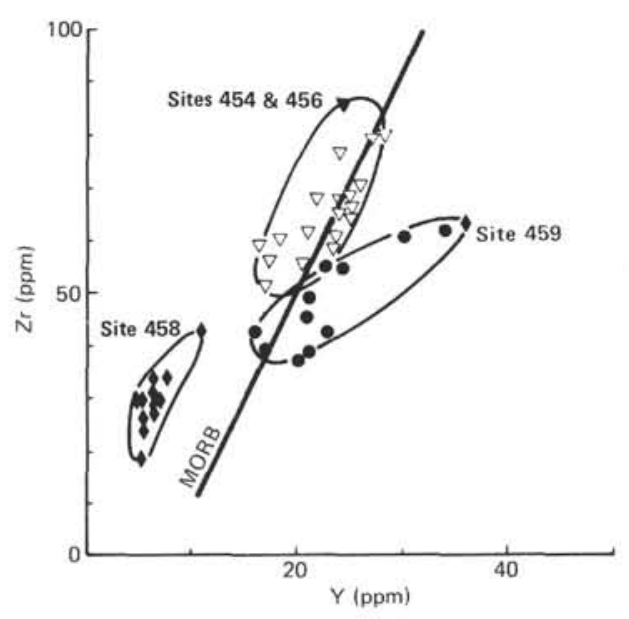

Figure 7. $\mathrm{Zr}$ vs. $\mathrm{Y}$ diagram for back-arc basin and fore-arc rocks. 